
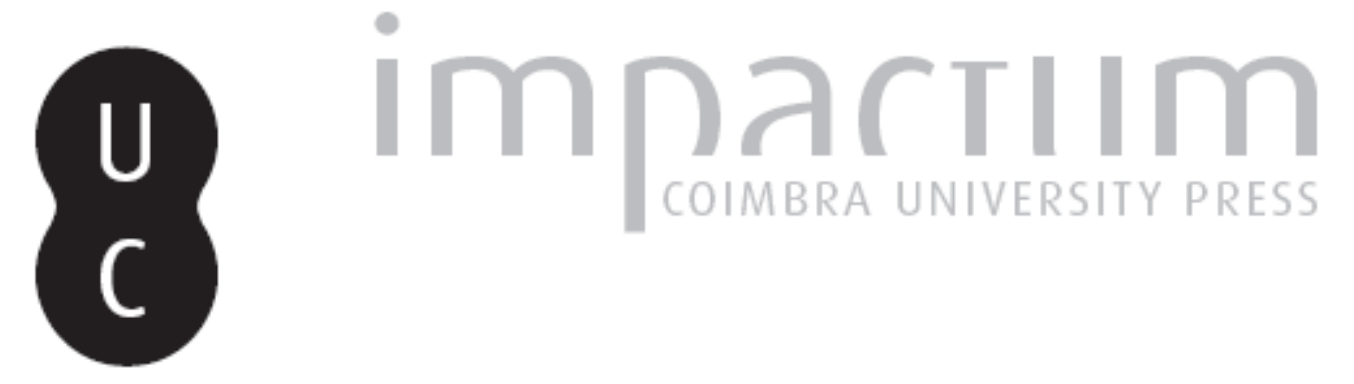

Verdi e o gosto pela ópera italiana em Portugal no século XIX

Autor(es): $\quad$ Borges, Maria José

Publicado por: Imprensa da Universidade de Coimbra

URL persistente:

URI:http://hdl.handle.net/10316.2/42425

DOI:

DOI:https://doi.org/10.14195/0870-8584_8_1

Accessed : $\quad$ 26-Apr-2023 12:22:52

A navegação consulta e descarregamento dos títulos inseridos nas Bibliotecas Digitais UC Digitalis, UC Pombalina e UC Impactum, pressupõem a aceitação plena e sem reservas dos Termos e Condições de Uso destas Bibliotecas Digitais, disponíveis em https://digitalis.uc.pt/pt-pt/termos.

Conforme exposto nos referidos Termos e Condições de Uso, o descarregamento de títulos de acesso restrito requer uma licença válida de autorização devendo o utilizador aceder ao(s) documento(s) a partir de um endereço de IP da instituição detentora da supramencionada licença.

Ao utilizador é apenas permitido o descarregamento para uso pessoal, pelo que o emprego do(s) título(s) descarregado(s) para outro fim, designadamente comercial, carece de autorização do respetivo autor ou editor da obra.

Na medida em que todas as obras da UC Digitalis se encontram protegidas pelo Código do Direito de Autor e Direitos Conexos e demais legislação aplicável, toda a cópia, parcial ou total, deste documento, nos casos em que é legalmente admitida, deverá conter ou fazer-se acompanhar por este aviso. 


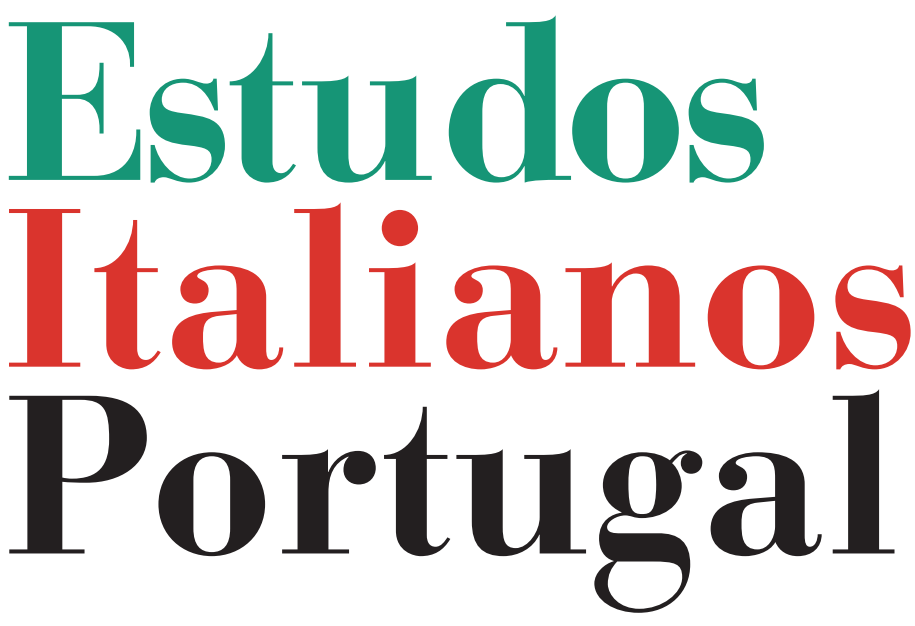

Instituto

Italiano

de Cultura

de Lisboa

Nova Série

$\mathbf{N}^{\circ} \mathbf{8}$ 


\title{
VERDI E O GOSTO PELA ÓPERA ITALIANA EM PORTUGAL NO SÉCULO XIX
}

\author{
Maria José Borges*
}

\section{OS ANTECEDENTES}

O GOSTO pela ópera italiana tem longínquas raízes em Portugal, implantando-se aqui já desde o século XVIII tanto ao nível da Corte, como da sociedade burguesa. Com efeito, desde o reinado de D. João V (1706-1750) que o estilo italiano estava francamente adoptado, indo os nossos compositores estudar para Itália ${ }^{1}$ (Roma, inicialmente, mais tarde Nápoles), compondo e escrevendo ao estilo italiano e contratando-se o napolitano Domenico Scarlatti para director musical da corte. E, mais particularmente, ainda, no reinado de D. José (1750-1777), em que se criou a Orquestra de virtuoses da Real Câmara e se reorganizaram as capelas reais

* Docente da Escola de Música do Conservatório Nacional onde, actualmente, lecciona História da Música e História da Cultura e das Artes. Licenciada em História (1982) e em Ciências Musicais (1988) e Mestre em Musicologia Histórica (2008) pela Universidade Nova de Lisboa. Tem-se dedicado, preferencialmente, à musicologia (conferências, colaborações, artigos, recensōes, etc.). Fez parte da Comissão Científica da reconstituição da Embaixada do Rei D. Manuel de Portugal ao Papa Leão X em 1514 (Lisboa, Expo Sevilha, 1992). Foi redactora especializada em diversos volumes da Nova Enciclopédia Larousse (1998), e co-autora nos vols. IX e X da Nova História de Portugal, dirigida pelos Profs. Joel Serrão e Oliveira Marques.

${ }^{1}$ Como os compositores António Teixeira e Francisco António de Almeida, bolseiros de D. João V, e João de Sousa Carvalho e Jerónimo de Lima, bolseiros de D. José, entre muitos outros. 
da Sé Patriarcal e do Palácio da Bemposta ${ }^{2}$, doravante dotadas de numerosos cantores, maioritariamente italianos, e com elevados ordenados, que nas ocasiōes solenes asseguravam os ofícios divinos da corte, ou cantavam nos espectáculos de ópera da mesma. Ainda nesse reinado se erguera, em 1755, um imponente e luxuoso Teatro de corte conhecido por Teatro ou Ópera do Tejo, decorado e dirigido por italianos ${ }^{3}$, de efémera existência, pois soçobrou no mesmo ano ao terrível terramoto que assolou Lisboa. Para além da corte, também na sociedade burguesa se vinha já desenvolvendo esse mesmo gosto desde finais do século XVIII ${ }^{4}$. Os três teatros de ópera do país foram todos, com efeito, fruto das diligências de grupos de burgueses: o Teatro Real de São Carlos (1793), tal como o de São João do Porto (1798) e mesmo o seu homónimo brasileiro no Rio de Janeiro (1813). Em todos foi rainha a ópera italiana.

Não será, pois, de estranhar que a ópera italiana continuasse a ser no século XIX o género mais cultivado, tanto pela aristocracia, como pela emergente burguesia, que via na ópera, para além do desfrute musical, um excelente palco social. Nos Teatros atrás referidos continuaram a instalar-se companhias italianas que apresentavam reportórios em italiano de autores de várias nacionalidades. $\mathrm{O}$ reportório que se ouvia era fundamentalmente clássico, constituído por óperas sérias, ou cómicas, sendo os autores mais representados Cimarosa, Paisiello, Marcos Portugal, Piccinni, entre outros, tal como acontecia, aliás, na maioria dos principais palcos europeus. Mozart, por exemplo, só será ouvido pela primeira vez em Portugal, em 1806, no Teatro de São Carlos 5 .

${ }^{2} \mathrm{Ou}$ os Paços da Rainha e dos Infantes.

${ }^{3}$ Com cenários de Bibiena e direcção musical do napolitano David Perez.

${ }^{4}$ Nos Teatros populares (da Rua dos Condes, do Salitre, ou do Bairro Alto) desenvolviam-se, pelo contrário, géneros operáticos em português, mais ligeiros, conhecidos como entremeses (em um acto), farsas (em vários actos) e burletas (simples traduções de libretos italianos de Metastasio, Goldoni e outros).

${ }^{5} \mathrm{Na}$ sua opera seria, La Clemenza di Tito, e mais tarde no Teatro de São João do 
Também no século XIX era ainda comum o uso de cantores castrati (na ópera e na música religiosa), segundo a moda italiana, pois, embora praticamente desaparecidos com o Classicismo no resto da Europa, D. Maria I proibira as mulheres de se apresentarem em palco, o que mantivera por mais tempo este tipo de cantores em Portugal, mesmo após o reaparecimento das cantoras. Entre eles o mais famoso foi G. Crescentini ${ }^{6}$, rival da célebre prima-donna Angelica Catalani, cantora preferida de Marcos Portugal.

Após as guerras liberais (1832-34), em que os próprios teatros de São João e São Carlos foram, inclusive, palco das movimentaçóes políticas, a sociedade romântica portuguesa vai continuar a privilegiar o espectáculo de ópera, pois esta tornara-se uma das formas de prestígio da burguesia, assumindo-se como uma espécie de passeio público da sociedade romântica, situação que se manteria até ao fim do século e para além dele 7 . A principal oferta continuava a ser, claro, a ópera italiana, nomeadamente do já celebrado Rossini, bastante em voga nos anos 20. Um autêntico sucedâneo de Rossini, o italiano Carlo Coccia, embora não tão genial nem tão apreciado como o original, foi maestro em São Carlos entre 1820-23 e João Evangelista Pereira da Costa apresentou em São Carlos, com alguma popularidade, óperas ao estilo de Rossini (Egilda de Provenza, 1828). Todavia, outros autores como Mercadante, Donizetti e Bellini, se começavam igualmente a impor. As temporadas dos dois teatros eram assaz

Porto, em 1815, na opera buffa, Cosí fan tutte (Cf. David Cramner, "As primeiras execuções em Portugal de óperas de Mozart", Actas do VI Encontro Nacional de Musicologia, Associação Portuguesa de Educação Musical, boletim 62, Julho-Setembro de 1989).

${ }^{6}$ Que viria a ser empresário do São Carlos.

${ }^{7}$ A este respeito consultem-se as obras de Mário Vieira de Carvalho, "Pensar é morrer" ou o Teatro de São Carlos na mudança de sistemas sociocomunicativos desde finais do século XVIII aos nossos dias, Lisboa, IN-CM, 1993 (em particular o cap. II), e de Augusto M . Seabra, Ir a São Carlos, Lisboa, Correios de Portugal, Ed. do Clube do Coleccionador dos Correios, 1993. 
semelhantes, embora o de São João apresentasse, como era usual, temporadas mais modestas ${ }^{8}$.

A direcção do São Carlos sob a égide do Conde de Farrobo 9 (1838-40) importante magnate, mecenas e melómano da época, foi um dos mais esplendorosos momentos do século, durante o qual se destacaram cantores italianos como o tenor Tamberlick e as cantoras Boccabadati e Rossi-Caccia que criaram legiões de entusiastas. Diz-se até que o Conde pretendera contratar logo em 1838, para director musical do Teatro, o então jovem de 25 anos G. Verdi, mas acabou por contratar outros maestros italianos, como Angelo Frondoni ${ }^{10}$ (1812-1891), que se radicou em Portugal nesse mesmo ano, e, no ano seguinte, Pietro Antonio Coppola, que, entre 1839 e 1871, compôs expressamente para o São Carlos diversas óperas ${ }^{11}$.

O episódio da possível contratação de Verdi para o São Carlos é referido, a posteriori, por diversos autores e tem fortes probabilidades de ser verídico. É preciso ter em conta que nesse ano de 1838 Verdi ainda não era o afamado compositor que se tornaria anos mais tarde, o que explicaria que o facto só fosse referido quando ele se tornou conhecido; e, como bem refere Luísa Cymbron, o empresário envolvido nas contratações com o então empresário de São Carlos (Antonio Lodi), nesse ano de 1838 era o mesmo que fez a apresentação das primeiras óperas de Verdi no Teatro alla Scala, com quem

\footnotetext{
${ }^{8}$ Tal se devia, fundamentalmente, à diferença de subsídios anuais que ambos recebiam do Estado: enquanto o Teatro de São Carlos recebia 20 contos de réis, o Teatro de S.João apenas recebia 4 contos de réis (cf. Luísa Cymbron, "A vida musical portuguesa na primeira metade do século XIX", Liszt em Lisboa. Catálogo da Exposição, Museu da Música, Lisboa, Instituto Português de Museus, 1995, p. 25).

${ }^{9}$ Joaquim Pedro Quintela, 2. ${ }^{\circ}$ barão de Quintela e primeiro conde de Farrobo.

${ }^{10}$ E que viria ser o autor do célebre Hino da Maria da Fonte.

${ }^{11}$ Para informaçôes mais completas sobre estes autores consulte-se, ainda, Maria José Borges, "A Música”, Nova História de Portugal, Coordenação de A. H. de Oliveira Marques, 2002, Vol. IX: Portugal e a instauração do Liberalismo, Cap. IX: A cultura literária, artística e musical, Lisboa, Editorial Presença, pp. 475-492.
} 
este empresário mantinha correspondência desde o ano anterior $^{12}$, sendo pois um elo de ligação entre ambos.

\section{O GOSTO POR VERDI}

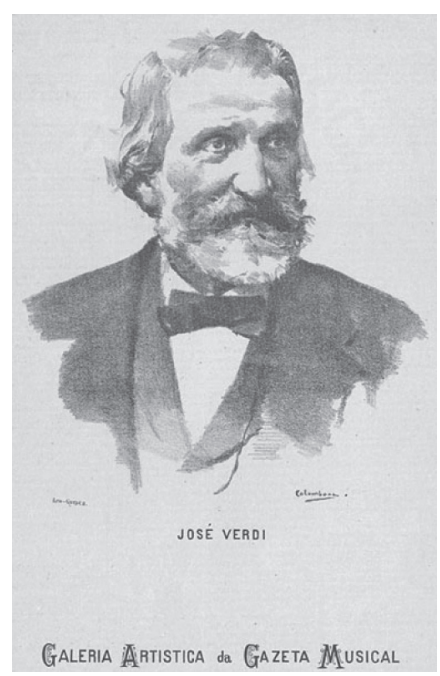

Retrato de Verdi por Columbano Bordalo Pinheiro.

É na década de 1840 que o gosto e verdadeira paixão por Verdi se instala francamente nos palcos (profissionais e amadores) e nos salōes da música doméstica portugueses, da capital e fora dela, para não o abandonar até quase finais do século.

Nabucco (a primeira ópera a dar-lhe notoriedade em Itália), é também a primeira obra estreada em Portugal, em $1843^{13}$. As opiniōes dos críticos acerca do espectáculo não

${ }^{12}$ Luísa Cymbron, "A produção e recepção das óperas de Verdi em Portugal no século XIX”, Verdi em Portugal (1843-2001). Catálogo da Exposição comemorativa do centenário da morte do compositor, Lisboa, Biblioteca Nacional, Teatro Nacional de São Carlos, 2001, p. 23.

${ }^{13}$ A 20 de Outubro de 1843, no Teatro São Carlos, no ano seguinte no Teatro São João do Porto e em 1846 numa versão de amadores, em concerto, pela Assembleia philarmónica. 
foram unânimes e são curiosas. Entre elas, $O$ Raio Theatral (5/11/1843) refere o "elevado talento do seu jovem autor", embora considere o espectáculo "um fiasco" quanto à interpretação e encenaçãoo ${ }^{14}$. Já na Revolução de Setembro (7-111843) (redigida por António Pedro Lopes de Mendonça), fazem-se consideraçôes musicais bastante negativas, referindo o autor das mesmas que "a expressão dramática não é nenhuma: não há uma ária, não há um duetto, não há uma só peça completa: a orchestra, mal conduzida e toda carregada de cheios, em semitons, e em setimas preparadas, que produzem os peiores effeitos" ${ }^{15}$. Luísa Cymbron, que o cita, caracteriza estas considerações como sendo fruto do "típico crítico literário", que não domina tecnicamente as questôes musicais, crítico este que se manteve céptico até muito tarde relativamente à música de Verdi, mesmo quando este já era autor consagrado ${ }^{16}$.

A seguinte apresentação de uma ópera de Verdi, Ernani $\left(1845^{17}\right)$, foi mais consensual e percebida como bastante inovadora. Particularmente no Porto foi perfeitamente entendida como sendo uma nova concepção dramática do autor, bem no contexto do espírito romântico, dizendo o articulista do Periódico dos Pobres que foi "a expressão musical (...) dos mais bellos pensamentos dramáticos de Victor Hugo (...)" e que o génio musical de Verdi se descobre no final do II acto, apresentando "musica que parece exprimir a ferocidade, e a raiva — novidade no acompanhamento do instrumental, que e (sic) trocado, e ao reves das regras da musica e da pratica dos outros compositores, resultando de tudo um effeito magico"18.

\footnotetext{
${ }^{14}$ Cf. Luísa Cymbron, "A produção e recepção das óperas de Verdi em Portugal no século XIX”, p. 24.

${ }^{15} \mathrm{Ib}$., p. 25.

${ }^{16} \mathrm{Ib}$

${ }^{17}$ Apresentada no mesmo ano em ambas as cidades.

${ }^{18}$ Periodico dos Pobres no Porto, 5-5-1845. Cit. por Luísa Cymbron, "A produção e recepção das óperas de Verdi em Portugal no século XIX”, pp. 25-26.
} 

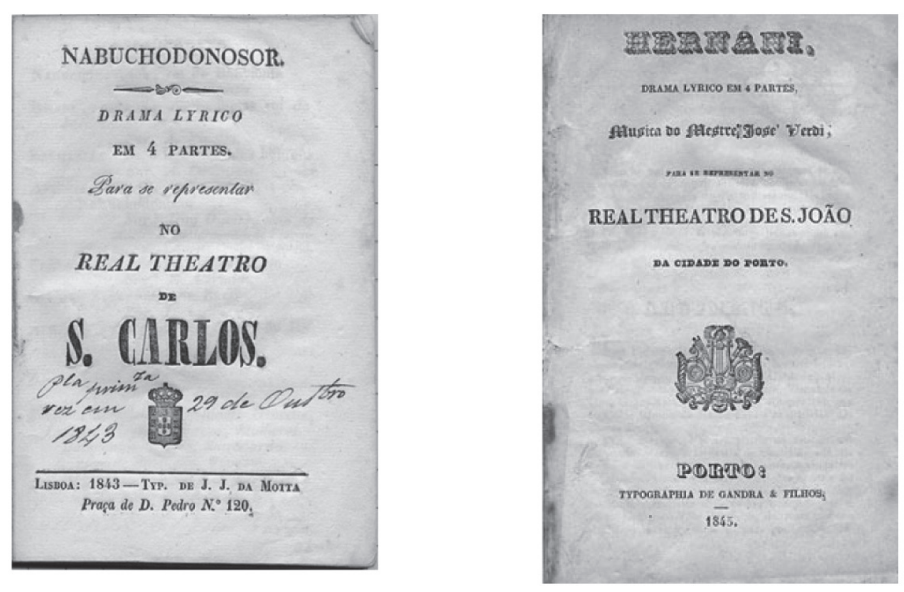

Libretos das óperas Nabuco e Ernani (em Lisboa e no Porto).

Nos anos seguintes, e até meados da década de 1850 foram estreadas em Portugal (quase sempre em Lisboa e só depois no Porto, salvo raríssimas excepçôes), as principais óperas de Verdi, relativamente próximas das suas datas oficiais de estreia. Foram elas I Lombardi... (1845), I due Foscari (1846), Attila, Giovanna d'Arco, Alzira (1847), I Masnadieri, Macbeth (1848-49), e, já nos anos de 1850, Rigoletto (1853), Il trovatore (1854), La traviata $(1855)^{19}$, as famosas óperas vulgarmente conhecidas como a trilogia popular de Verdi, curiosamente estreadas primeiro no Porto e só depois em Lisboa. O Teatro de São João do Porto encontrava-se, agora, não esqueçamos, num período florescente, sob a regência do maestro italiano Carlos Dubini (1826-1883), radicado no Porto desde cerca de 1845.

${ }^{19}$ Veja-se a este propósito, o artigo de Carmina Carvalheiro, "Estreias de obras de Verdi em Portugal até à morte do compositor", Verdi em Portugal (1843-2001), pp. 87-92.

${ }^{20}$ Cf. Luisa Cymbron, "A produção e recepção das óperas de Verdi em Portugal no século XIX”, p. 26. 
Particularmente bem recebida pelo público foi Macbeth, com grande afluxo de público e várias enchentes consecutivas $^{20}$, em que o geralmente céptico Lopes de Mendonça, atrás referido, chegou a salientar que "o elemento phantastico completa a idéa grandiosa de Shakespeare, e realça o talento de Verdi. Os coros das feiticeiras são magníficos, e sem querer, o expectador quasi que chega a partilhar a commoção supersticiosa do usurpador, que cede às vagas prophecias das irmãs do destino"21. Para o sucesso do espectáculo muito contribuíram também os magníficos cenários concebidos por Cinnati e Ramboi, que infelizmente não enriqueceram a apresentação no Porto devido à menor dimensão do palco. A cena do III acto aparecerá, inclusive, impressa numa litografia da época.

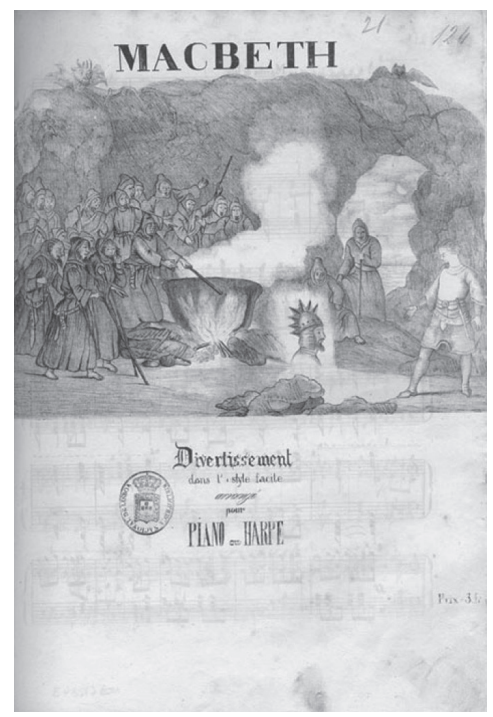

Partitura com a litografia de cena do III acto de Macbeth.

\footnotetext{
${ }^{21}$ Ib., pp. 26-27.
} 
Fora dos principais teatros já referidos e em contextos amadores, também se representaram óperas completas de Verdi, nomeadamente em Lisboa, na Assembleia Philarmónica, presidida pelo Conde de Farrobo, onde se incluíam membros da alta sociedade lisboeta, como o próprio Conde de Farrobo e seus familiares e apaniguados. Aí se ouviram as óperas Ernani (1845), I due Foscari e Nabucco (em versão de concerto; 1846), esta última muito elogiada nas crónicas sociais da época, nomeadamente na Revolução de Setembro ${ }^{22}$; ou na Academia Filarmonica, onde se ouviu Alzira (1847).

No contexto da música doméstica e amadora o sucesso de Verdi ampliava-se, ainda, através de abundantes paráfrases instrumentais das suas óperas mais em voga, nomeadamente transcriçōes para piano, para violino, ou flauta, ou conjuntos instrumentais, disponibilizadas em cópias manuscritas, ou editadas pelas casas editoras de música que se iam instalando na época, nomeadamente os editores Ziegler, Canongia, Neuparth e Sassetti, desenvolvendo-se nos abundantes virtuosismos das paráfrases, variações, pot-pourris, fantasias, etc., sobre trechos do reportório verdiano em voga nesta época ${ }^{23}$.

$\mathrm{Na}$ segunda metade do século XIX, a cultura romântica burguesa, com características semelhantes às que caracterizaram o romantismo europeu em geral, encontra-se já definitivamente instalada em Portugal, onde, também a Música se torna uma actividade maioritariamente burguesa e laica, tanto no consumo como nas estruturas em que se desenvolveu.

A década de 1850 representa, de certa forma, uma importante viragem na apreciação e consolidação das óperas de Verdi, particularmente pelo grande sucesso obtido pela sua trilogia popular. É nessa década, aliás, que o Teatro de São Carlos será adquirido pelo Estado (1854) e que importan-

${ }^{22}$ Cf. ib., p. 25.

${ }^{23}$ Vide ilustração anterior. A este propósito, leia-se o artigo de Francesco Esposito, "O sucesso de Verdi na música pianística: as ediçōes musicais lisboetas do século XIX", Verdi em Portugal (1843-2001), pp. 41-58. 
tes melhoramentos serão efectuados a nível da instalação e disposição da orquestra no sentido de melhorar a qualidade sonora em produções da trilogia, reagindo a críticas do compositor e crítico Emílio Lami. Este, num artigo em que analisava o papel da orquestra nas óperas de Verdi, diz, de forma bastante assertiva, que "a maneira de empregar a orchestra é para Verdi um dos grandes auxiliares para a homogeneidade que elle tão admiravelmente estabelece entre a sua musica e a poesia. Verdi não considera a orchestra como um acessório, e tem a convicção de que, para o compositor dramático, ella se torna uma parte importantíssima (...) mas também porque esta dá ao compositor (...) muito mais recursos (...) para a perfeita tradução da poesia na linguagem musical. E tanto é assim, que a uma certa e determinada melodia se podem dar caracteres inteiramente oppostos, somente pela distribuição da instrumentação" 24 . E, nesse contexto, meses mais tarde, na temporada de La traviata, faz algumas críticas contundentes à orquestra do São Carlos: as cordas quase não se ouviam, a orquestra actuava num estrado demasiado pequeno para o número de elementos que a compunha (47 músicos), obrigando os sopros a ficarem fora do estrado, e a posição dos metais nos dois extremos da orquestra e das madeiras, entre as cordas e o público abafavam a fraca sonoridade das mesmas $^{25}$. Na temporada seguinte fizeram-se importantes modificações no âmbito da orquestra, registadas positivamente pelo referido crítico, o que leva Luísa Cymbron a considerar o dado interessante de que a música de Verdi foi, de facto, "o impulso" que levou à "alteração das estruturas de produção do principal teatro de ópera português" ${ }^{26}$.

${ }^{24}$ In $O$ Trovador, 26 de Maio de 1855, cit. por Luísa Cymbron, "A produção e recepção das óperas de Verdi em Portugal no século XIX”, p. 31.

${ }^{25}$ Luísa Cymbron, "A produção e recepção das óperas de Verdi em Portugal no século XIX”, p. 31.

${ }^{26} \mathrm{Ib}$. 
Quanto à ópera La traviata, esta mereceu ao já referido Emílio Lami as seguintes considerações: "A partitura da Traviata é o mais poderoso argumento que se pode apresentar contra os que acusam Verdi de falta de melodias: alli tudo é canto puro, expressivo e inspirado (...). A musica da Traviata é philosophica; Verdi poz de parte tudo o que havia de velho na forma e no desenvolvimento dos trechos; (...) e a sua musica, em vez de ser convencional (...) tornou-se lógica e razoável (...). Não é só a Traviata; ahi estão Luiza Miller, Trovatore, e especialmente Rigoletto para servirem de modelo aos compositores que se quiserem affastar do convencionalismo a que a musica tem estado sujeita"27.

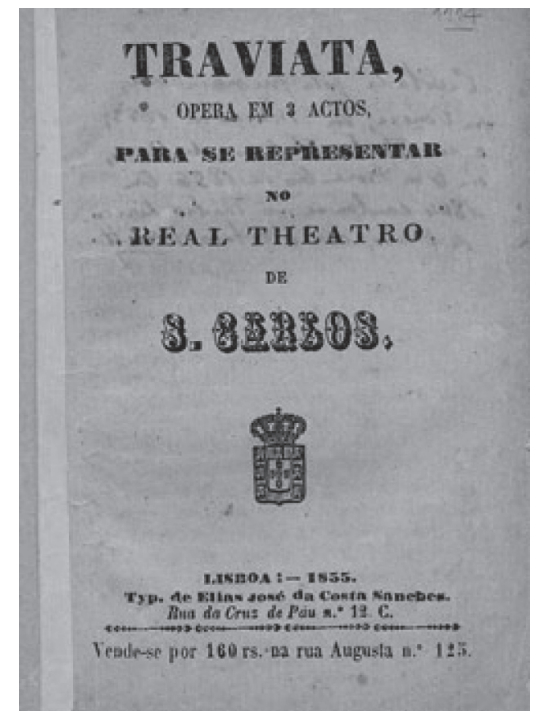

Libreto de La traviata.

${ }^{27}$ In O Trovador, 31 Out. 1855, cit. por Luísa Cymbron, "A produção e recepção das óperas de Verdi em Portugal no século XIX”, p. 30. 
A partir da década de 1860 , fruto da acção inovadora do seu então empresário, e também músico Guilherme Cossoul $^{28}$, o reportório de São Carlos inclui cada vez mais óperas de autores franceses nunca antes apresentadas, (Meyerbeer, Gounod, Auber, Thomas), quase todas, porém, em versão italiana $^{29}$, mas Verdi continuará a ser um autor recorrente, representando as suas óperas (antigas e/ou novidades), cerca de 38 por cento da programação do teatro, percentagem ainda maior no teatro de São João no Porto ${ }^{30}$, sendo Ernani e Macbeth as óperas mais representadas em Lisboa e Il trovatore a mais representada no Porto ${ }^{31}$. As óperas novas serão ouvidas só quase uma década depois, optando-se nitidamente por alguma estagnação e rotina do reportório verdiano, o que terá levado, presumivelmente à frase dita em 1873 e recorrentemente referida e repetida acerca da produção do São Carlos: "sempre Trovador, sempre Rigoleto, sempre Traviata" ${ }^{2}$. Por exemplo, La forza del destino, embora tenha sido comprada a sua partitura logo em 1862-63 pelo São Carlos, directamente à casa Ricordi, só foi aqui ouvida em 1869. E Don Carlo seria ouvido primeiro no Porto (18 de Fevereiro de 1870) no recentemente construído Palácio de Crista ${ }^{3}$ e apenas no ano seguinte em Lisboa, onde aliás foi pateada no V acto, considerado demasiado longo, e abolido a partir daí

\footnotetext{
${ }^{28}$ Seu empresário entre 1864 e 1873 . Cossoul foi também o primeiro bombeiro voluntário em Portugal...

${ }^{29}$ Excepção feita a uma série de óperas de Adam, Auber, Paer e Halevi, entre outros, apresentadas em 1878 por uma companhia francesa de opéra comique, que se apresentou após terminar a temporada lírica italiana (Vide M. V. de Carvalho, "Pensar é morrer" ou o Teatro de São Carlos, p. 357).

${ }^{30}$ Luísa Cymbron, "A produção e recepção das óperas de Verdi em Portugal no século XIX”, p. 32.

${ }^{31} \mathrm{Ib} .$, p. 33

${ }^{32}$ Ib., p. 21. Segundo a referida musicóloga, da presumível autoria de Tomás Lino da Assunção, O Subsídio ao Theatro de S. Carlos (1872-1873).

${ }^{33}$ Construído para a Exposição Industrial no Porto de 1865.
} 
nas restantes récitas(! $)^{34}$. Tais diatribes foram deliciosa iguaria para as mordazes ironias de Eça de Queiroz na sua obra Uma campanha alegre...

Tardia, também, foi a vinda da famosa Aida (Lisboa, 1878; Porto, 1880), mas porque o seu sucesso e concorrência provável entre teatros a fez demorar. De dispendiosa e complexa montagem, "uma bizarria", no dizer de Benevides ${ }^{35}$, foi por este considerada "um espectáculo esplêndido (que) esmagava todas as outras óperas"36, ao passo que o redactor da revista Ocidente, critica algumas falhas da encenação (elogiando, embora o décor e as pinturas, que seriam as últimas, aliás da dupla Cinatti e Rambois), o pouco rigor histórico, os trajes, etc. ${ }^{37}$. O pormenor das trombetas egípcias, concebidas de propósito para esta ópera, foi bastante salientado, referindo-se na Revolução de Setembro o seu "admirável effeito" e dizendo-se, até, que, ao contrário da dificuldade que houvera lá fora em encontrar executantes, aqui em Portugal até se arranjaram músicos de reforço ${ }^{38}$. Todavia, outros mais atentos, deram conta da má colocação em cena, permitindo ver um conjunto de instrumentos modernos (saxofones) que estragavam o efeito pretendido ${ }^{39}$.

${ }^{34}$ Luísa Cymbron, "A produção e recepção das óperas de Verdi em Portugal no século XIX”, p. 34.

${ }^{35}$ Francisco Benevides, autor de O Real Theatro de S. Carlos (1883).

${ }^{36}$ Citado por Luísa Cymbron, "A produção e recepção das óperas de Verdi em Portugal no século XIX”, p. 34.

${ }^{37} \mathrm{Ib}$.

${ }^{38} \mathrm{Ib}$., p. 36.

${ }^{39} \mathrm{Ib}$. 


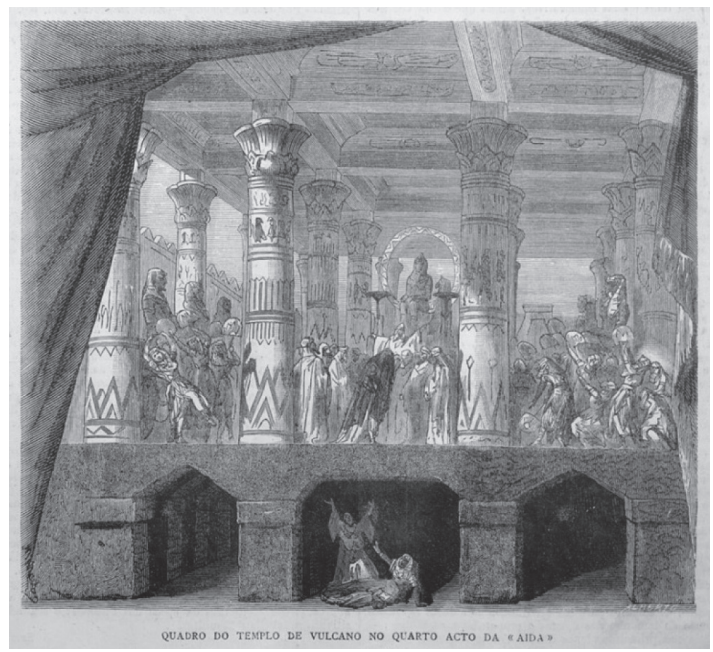

Litografia com cenário do IV acto de Aïda, em São Carlos (1878).

Para além das óperas de Verdi, até à década de 1880 o São Carlos manteve como única oferta um reportório exclusivamente em italiano, embora de proveniência muito diversificada e em que as óperas de Meyerbeer começavam a fazer uma séria concorrência. A partir da década de 1880, o predomínio das companhias italianas é agora repartido com companhias francesas e alemãs, apesar do público continuar a preferir o brilhantismo do belcanto italiano nas interpretaçôes de carismáticos cantores que entusiasmaram as plateias de São Carlos ${ }^{40}$. A partir de 1882 irão estrear-se algumas das primeiras óperas de Wagner nunca antes ouvido em Portugal como Lohengrin, mas em versão francesa e com pouca receptividade do público. A partir da década de 80 é o reportório verista ${ }^{41}$ (Bizet, Leoncavallo, Puccini, etc.) que vai ganhando

${ }^{40}$ Como Enrico Tamberlick (tenor), Fortunata Tedesco (mezzo), Adelina Patti (soprano), Francesco Tamagno (tenor), e ainda a semi-portuguesa Regina Pacini.

${ }^{41} \mathrm{O}$ Verismo é a corrente realista, ou naturalista, da ópera italiana de finais do século XIX, representada por vultos como Pietro Mascagni, R. Leoncavallo e G. Puccini. 
cada vez mais terreno e, na década seguinte, a presença de Wagner, já em alemão começa a tornar-se algo constante ${ }^{42}$.

Ainda em italiano eram as diversas óperas dos compositores portugueses estreadas em São Carlos ao longo desta segunda metade do século XIX ${ }^{43}$. Com efeito, quase até ao fim do século XIX, as óperas de autores portugueses eram em reportório italiano, não apenas, porque as companhias de ópera nos principais teatros de ópera eram maioritariamente constituídas, ainda, por cantores italianos, mas também devido ao facto de se considerar que a língua portuguesa era pouco cantabile. Estão neste caso as de autores como Francisco Xavier Migone, de Francisco Sá Noronha, de Miguel Ângelo Pereira, entre outros, e do próprio Alfredo Keil, apesar de ser dele a primeira ópera escrita em português $A$ serrana $(1899)^{44}$.

Os gostos musicais, tal como já acontecera na primeira metade do século XIX, irão permanecer preponderantemente italianos e demasiado operáticos até ao último quartel do século XIX, apesar de progressivamente franceses, sobretudo desde a criação da linha ferroviária Lisboa-Paris em 1887.

Verdi continua a ser ouvido nas suas novas produções, nomeadamente Otello, ouvido em Lisboa em 1889 e de Falstaff, em 1894, tendo esta última merecido uma referência na correspondência entre Verdi e o seu amigo e libretista da ópera, Arrigo Boito, ao referir-se ao seu cansaço dizendo : "trabalhei estes dias para os três pançudos de Lisboa, Berlim

\footnotetext{
${ }^{42}$ Não ainda o Wagner do drama musical consubstanciado na sua concepção de Obra-de-Arte-total (Gesamtkunstwerk) que só no século XX (1909) chegará até nós, e por companhias alemãs.

${ }^{43}$ Veja-se a este propósito, mais desenvolvidamente, o artigo da autora destas linhas "A música (1850-1900)", Nova História de Portugal. Direcção de A.H. de Oliveira Marques, 2004, Vol. X: Portugal e a Regeneração, cap.VIII, Linhas gerais da cultura, Lisboa, Editorial Presença pp. 392-410.

${ }^{44}$ Conforme o próprio autor afirma na sua dedicatória autógrafa a seu amigo Massenet, que actualmente se encontra na Biblioteca Nacional de Lisboa.
} 
e Nápoles!...Coisas bonitas mas também um pouco aborrecidas!" 45 . E ouvido, também, nas suas produções mais antigas, nomeadamente em Aida que Luísa Cymbron considera "o verdadeiro pilar do reportório verdiano entre nós nesse período" repetidamente representado desde a sua estreia até 1901, data da morte do compositor, em quase todas as temporadas $^{46}$.

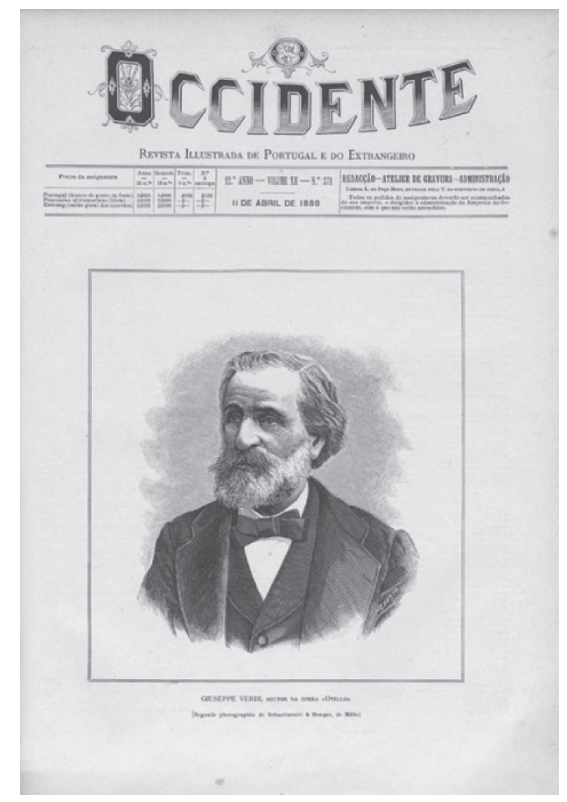

Capa da revista Occidente (1889), dedicada a Verdi ("author de Othelo”).

$\mathrm{Na}$ fase final do século XIX Verdi será ouvido não apenas nos Teatros de ópera da capital e do Porto, a que agora se acrescentam o Coliseu dos Recreios, em Lisboa e o Palácio de

${ }^{45}$ Luísa Cymbron, "A produção e recepção das óperas de Verdi em Portugal no século XIX”, p. 38.

${ }^{46} \mathrm{Ib}$., p. 39 
Cristal, do Porto, mas também na província (Viseu: Teatro Boa União) e nas Ilhas (Ponta Delgada: Teatro Micaelense) ${ }^{47}$. E começará, também, a ser progressivamente confrontado com Wagner, considerado agora o grande cultor da chamada música filosófica, de origem germânica, como já antes aqui fora considerado Meyerbeer, e até o próprio Verdi, acusado inicialmente de ausência do melodismo tão caro à ópera italiana.

O grande culto pela música operática e pelo italianismo na música do século XIX em Portugal foi criticado por muitos musicólogos de formação germânica, como Joaquim de Vasconcelos ${ }^{48}$, entre outros, pois foi costume considerar-se a produção de música cénica como esteticamente inferior em relação à música instrumental. No entanto, o mesmo se passou em relação a muitos outros países da Europa como a França e particularmente a Itália que, à semelhança de Portugal, seguiram preferencialmente um romantismo mais operático que instrumental. Com efeito, o Romantismo musical que entre nós se instalou, pelo menos numa fase inicial, aconteceu maioritariamente por via do belcanto italiano (e também da grand-opera francesa) e menos significativamente por influência de uma cultura de raiz germânica mais orientada para a música pura.

Nesse declarado gosto pelo belcanto italiano, Verdi tem ocupado, sem dúvida, um papel de intenso relevo, e não apenas no século XIX, lugar que se vem mantendo, podemos afirmar, até aos nossos dias, pois ao longo de todo o século $\mathrm{XX}$ e até à actualidade, foi um autor recorrentemente apresentado na cena operática portuguesa ${ }^{49}$, o que não tem acontecido com tantos outros, mesmo em anos de efemérides, nem mesmo com os nossos autores nacionais ${ }^{50}$.

\footnotetext{
${ }^{47}$ Consulte-se para mais detalhes o artigo de Carmina Carvalheiro, "Estreias de obras de Verdi em Portugal até à morte do compositor".

${ }^{48}$ Críticas bem patentes na sua obra Os Músicos portuguezes, 2 vols., Porto, 1870.

${ }^{49}$ Sobre a continuidade e recorrência das obras de Verdi, pelo menos em São Carlos, até ao ano de 2001, consulte-se o artigo de Rui Vieira Nery, "Um século de vozes
} 
28 Maria José Borges

verdianas no São Carlos (1901-2001)", Verdi em Portugal (1843-2001), pp.59-85. E, como curiosidade, refira-se ainda que, na madrugada em que se deu a revolução de 25 de Abril de 1974, ouvia-se no Coliseu dos Recreios a sua Traviata, em que a autora destas linhas esteve, também, presente...

${ }^{50}$ As ilustrações que acompanham o artigo foram reproduzidas a partir do volume Verdi em Portugal. 